Genij Ortopedii, Vol. 25, no 4, 2019

(c) Soldatov Yu.P., Stogov M.V., Ovchinnikov E.N., Gubin A.V., Gorodnova N.V., 2019

DOI 10.18019/1028-4427-2019-25-4-588-599

\title{
Evaluation of clinical efficacy and safety of the llizarov apparatus for external fixation (literature review)
}

\author{
Yu.P. Soldatov ${ }^{1}$, M.V. Stogov ${ }^{1}$, E.N. Ovchinnikov ${ }^{1}$, A.V. Gubin ${ }^{1}$, N.V. Gorodnova ${ }^{2}$ \\ ${ }^{1}$ Russian Ilizarov Scientific Center for Restorative Traumatology and Orthopaedics, Kurgan, Russian Federation, \\ ${ }^{2}$ Ural Federal University, Ekaterinburg, Russian Federation
}

\begin{abstract}
Purpose A retrospective analysis of clinical efficacy and safety of using the external fixation apparatus of G.A. Ilizarov's design. Materials and methods Analysis and evaluation of clinical data was performed using 107 literary sources. 4.200 clinical cases were studied to evaluate effectiveness, and 6.274 cases to assess safety. Results The analysis revealed a high clinical efficacy of using the Ilizarov apparatus for external fixation (various assemblies) in solving a wide range of practical problems in the field of traumatology and orthopedics. According to the results of the study, its high clinical treatment effectiveness was confirmed both on the use of the method in general (about $95 \%$ of positive outcomes), and in specific nosological groups of patients (not lower than $90 \%$ of positive outcomes). After having assessed the available data on the safety in the application of the Ilizarov apparatus for external fixation (various assemblies), we can conclude that the rates of adverse events, recorded in the literature analyzed, can be considered acceptable. Among all those events, the events classified as adverse effects of the product amounted to $17.03 \%(5 \div 95 \% \mathrm{CI}$ : $16.11 \div 17.97 \%)$.
\end{abstract}

Keywords: Ilizarov apparatus, clinical efficacy and safety

\section{INTRODUCTION}

The external fixation apparatus developed by G.A. Ilizarov has been used in contemporary surgical practice and provides significant rates of positive results in the treatment of a wide range of pathology of the musculoskeletal system [1-3]. Technologies combining the Ilizarov apparatus with other methods have been also developed and are aimed at treating patients with orthopedic and traumatic pathologies [4-10].

Along with the accumulation of experience in the use of the external fixation apparatus, a number of problems were identified such as risks of developing joint contractures, vascular and neurological complications; "ischemic" regenerates; penetration of infectious agents along the structural elements of the external fixation apparatus that pass into the bone [11-22].

At present, the demand for the Ilizarov external fixation apparatus and its components for implementation of the technologies of transosseous osteosynthesis for treatment of patients with injuries and orthopedic pathology has been growing [23, 24].

Therefore, the goal of our study was to objectify clinical and management risks of using the Ilizarov apparatus. The study is devoted to assessing clinical efficacy and safety of the Ilizarov apparatus in practical traumatology and orthopedics.

\section{MATERIAL AND METHODS}

The analysis of clinical efficacy and safety was based on the literature reports that discuss the experience of using the Ilizarov external fixation apparatus.

Clinical Data Search Strategy A systematic search for data on the use of the Ilizarov apparatus was conducted in open electronic databases of scientific literature at PubMed and eLIBRARY platforms, as well as the collection of the Medical Library of the Federal State Budgetary Institution Russian Ilizarov Scientific Center for Restorative Traumatology and

Soldatov Yu.P., Stogov M.V., Ovchinnikov E.N., Gubin A.V., Gorodnova N.V. Evaluation of clinical efficacy and safety of the Ilizarov apparatus for external fixation (literature review). Genij Ortopedii, 2019, vol. 25, no 4, pp. 588-599. DOI 10.18019/10284427-2019-25-4-588-599. (In Russian) 
Orthopaedics of the Ministry of Health of Russia, the world's leading institution for clinical application of the Ilizarov transosseous osteosynthesis technologies.

The following keywords were used to search for clinical data: "transosseous osteosynthesis", "apparatus", "Ilizarov method", "Ilizarov" (in Russian and English versions).

To analyze and evaluate the clinical data, the following criteria were defined for inclusion and exclusion of sources into the study.

Inclusion criteria:

1) full-text sources or structured abstracts with available specific quantitative data;

2) clinical studies stating that patients were treated using the Ilizarov transosseous osteosynthesis techniques or the Ilizarov method and/or apparatus;

3) sources that contain quantitative data on the evaluation of treatment results regarding its effectiveness and safety (the number of positive/ negative treatment outcomes, rating scales, number of complications, etc.), indicating the authors and/or the name of the rating systems and tests used.

Exclusion criteria:

1) studies in which transosseous osteosynthesis technologies were used in combination with other techniques;

2) clinical cases, pilot and preliminary studies;

3) "duplication" studies (a similar study protocol, similar groups and number of patients, a similar team of authors, etc.). If "duplicate" articles were found, a source with a more recent publication date was chosen.

Separately, scientific sources containing research data were analyzed that compared the effectiveness and safety of the clinical use of the Ilizarov apparatus for external fixation with other methods and technologies applied in orthopedics and traumatology.

Primary and secondary endpoints to evaluate product performance

Primary endpoints (rates of positive treatment outcomes at the time of dismantling the Ilizarov):

- bone consolidation;

- lengthening magnitude achieved as planned;
- defect/deformity correction;

- arthrodesis achieved;

- positive treatment outcomes according to clinical and functional rating scales.

Secondary endpoints (rates of positive outcomes at long term follow-up (more than one year after the dismantling of the device)):

- according to clinical and functional evaluation scales;

- treatment results preserved.

Endpoints for assessing product safety - rates of severe adverse events and adverse effects recorded during product performance.

The definition of adverse events and their categorization in this study is accepted in accordance with GOST R ISO 14155-2014 "Clinical studies. Good clinical practice" (paragraphs 3.1, 3.2, 3.15, 3.36, 3.37, 3.42).

The following grading was applied to evaluate the cause-effect relationship between the medical device and an undesirable event in this study: reliable, probable, likely, unlikely relationship or no relationship (Letter of health care inspection body Roszdravnadzor dated 28.12.2012 No. 04I-1310/12 "On the procedure of monitoring the safety of medical products in clinical trials ").

Prior to the study, a written approval was obtained from the institutional ethics committee. The study was conducted in accordance with ethical standards established in the Helsinki Declaration, applicable law and applicable regulatory requirements.

Mathematical analysis of retrospective data included a quantitative analysis of the results of previous studies, including data on the effectiveness and safety of the product. Quantitative primary and secondary criteria for evaluating the effectiveness and safety were summarized in tables and presented using descriptive statistics in the form of absolute and relative values (percentage of the total), $5 \div 95$ percent confidence interval (5-95 \% CI). Missing data are marked in the tables as "no data" and were not taken into account in general statistics. 
Literature sources included in the study for the analysis of efficacy and safety, containing the data on primary and secondary endpoints, are presented in the list of references [25-131].

Data on efficacy All sources were grouped into four sections according to the pathology groups in accordance with the main purposes of the Ilizarov apparatus application formulated by the author himself:

- closed reduction and fixation of bone fragments in fractures and nonunion;

- operative and bloodless limb lengthening;

- correction of deformities and management of long bone defects without bone grafts;

- compression arthrodesis of large joints or elimination of stiff contractures.

Summarized findings on the efficiency of the Ilizarov external fixation apparatus are given in Table 1.

The results of the summary demonstrate that at the end of treatment (removal of the device, primary endpoint), the rates of positive outcomes in treating patients with pathologies of the musculoskeletal system using the Ilizarov apparatus ranged from 91.43 to $98.75 \%$, and at the time of a long term follow-up (secondary endpoint) they ranged between 90.91 and $100 \%$. Such fluctuations in the rates are associated with the features of the pathology for which the Ilizarov apparatus was used.

The summarized data on the efficiency of the Ilizarov apparatus showed the following:
- a total of 82 scientific literature sources were included into the study for the analysis and evaluation of clinical data according to the inclusion and exclusion criteria;

- 4,200 cases were included to calculate the rates of positive outcomes resulting from the treatment at the time of dismantling the device (primary endpoint);

- a total of 4,031 positive outcomes of treatment was recorded in the reports included (bone consolidation, planned elongation, defect bridging, deformity correction, arthrodesis were achieved; grading of clinical and functional rating scales: "fair result" and higher);

- clinical efficacy of the Ilizarov apparatus for external fixation at the time-point of its dismantling was $95.98 \%(5 \div 95 \%$ CI: $95.37 \div 96.55 \%)$;

A total of 1,644 cases were analyzed to calculate the rate of positive treatment outcomes at long-term follow-ups (secondary endpoint);

- positive outcomes of treatment reported were 1,560 cases (bone consolidation and elongation preserved, bone integrity in the area of the defect, absence of deformity recurrence, fusion maintained in arthrodesis; grading of clinical and functional rating scales were "fair" and higher);

- clinical efficacy of the Ilizarov apparatus for external fixation in regard to treatment results preserved in the long term (more than one year after dismantling) was $94.89 \%(5 \div 95 \% \mathrm{CI}$ : $93.77 \div 95.90 \%$ ).

Table 1

Summarized data on the efficacy of the Ilizarov apparatus for external fixation for treatment of patients with pathology of the musculoskeletal system

\begin{tabular}{|c|c|c|c|}
\hline Product designation & $\begin{array}{c}\text { Number of } \\
\text { sources }\end{array}$ & 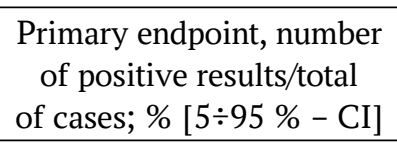 & 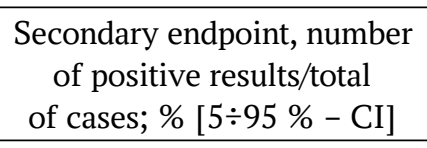 \\
\hline $\begin{array}{l}\text { closed reduction and fixation of bone } \\
\text { fragments in fractures and nonunion }\end{array}$ & 31 & $\begin{array}{l}1029 / 111292.54 \% \\
{[90.92 \div 94.01]}\end{array}$ & $\begin{array}{c}720 / 75195.87 \% \\
{[94.33 \div 97.17]}\end{array}$ \\
\hline operative and bloodless limb lengthening & 9 & $\begin{array}{c}475 / 48198.75 \% \\
{[97.56 \div 99.55]}\end{array}$ & $\begin{array}{l}48 / 48100 \% \\
{[98.01 \div 100]}\end{array}$ \\
\hline $\begin{array}{l}\text { correction of deformities and management } \\
\text { of long bone defects without bone grafts }\end{array}$ & 35 & $\begin{array}{c}2335 / 239797.41 \% \\
{[96.74 \div 98.01]}\end{array}$ & $\begin{array}{c}762 / 81293.84 \% \\
{[92.08 \div 95.39]} \\
\end{array}$ \\
\hline $\begin{array}{l}\text { compression arthrodesis of large joints or } \\
\text { elimination of stiff contractures }\end{array}$ & 7 & $\begin{array}{c}192 / 21091.43 \% \\
{[87.28 \div 94.83]} \\
\end{array}$ & $30 / 3390.91 \%[78.93 \div 98.17]$ \\
\hline Total: & 82 & $\begin{array}{l}4031 / 420095.98 \% \\
{[95.37 \div 96.55]}\end{array}$ & $\begin{array}{c}1560 / 164494.89 \% \\
{[93.77 \div 95.90]}\end{array}$ \\
\hline
\end{tabular}


To further evaluate the effectiveness of the Ilizarov apparatus, sources that compared the effectiveness of the clinical application of the Ilizarov apparatus for external fixation with other methods and technologies used in orthopedics and traumatology were analyzed.

A total of 12 comparative studies were found.

The effectiveness of using the Ilizarov apparatus for external fixation did not significantly differ from the one shown for the methods compared in eight studies.

The merits of Ilizarov transosseous osteosynthesis technologies using the apparatus for various pathologies were shown in four works. In particular, the authors refer the following to the advantages of the treatment with the Ilizarov apparatus:

- a shorter inpatient stay [91];

- a shorter time of fracture union [94];

- a shorter time of temporal disability [81];

- lower financial costs for treatment and subsequent rehabilitation [128].

Safety data All sources were also grouped into four sections according to the groups of pathologies, in accordance with the main purposes:

- closed reduction and fixation of bone fragments in fractures and nonunion;

- operative and bloodless limb lengthening;

- correction of deformities and management of long bone defects without bone grafts;

- compression arthrodesis of large joints or elimination of stiff contractures.

Summarized data on groups of all the cases reported in the sources included in the study on the clinical use of the Ilizarov apparatus of external fixation that developed adverse events are given in Table 2.

The results presented in the Table show that the list of complications and adverse events and their incidence vary and depend on the pathology for which the Ilizarov apparatus was used.

Summarized data on all cases of adverse events reported in the sources included into the study that discuss the clinical use of the Ilizarov apparatus (in various configurations) for external fixation are given in Table 3.

Table 2

Summarized data on the safety of the Ilizarov apparatus for external fixation in the treatment of patients with pathology of the musculoskeletal system

\begin{tabular}{|c|c|c|c|}
\hline $\begin{array}{c}\text { Product } \\
\text { designation }\end{array}$ & $\begin{array}{l}\text { Number } \\
\text { of sources }\end{array}$ & Adverse events $(A E)$ & $\begin{array}{l}\text { Severe adverse events } \\
(S A E)\end{array}$ \\
\hline $\begin{array}{l}\text { closed reduction } \\
\text { and fixation of } \\
\text { bone fragments } \\
\text { in fractures and } \\
\text { nonunion }\end{array}$ & 27 & 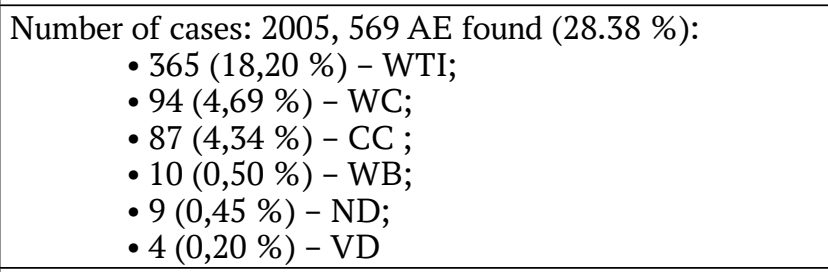 & $\begin{array}{l}\text { Number of cases: } 2055^{*} \\
45 \text { SAE }(2.19 \%) \text { found: } \\
\text { - } 41(2.00 \%) \text { - osteomyelitis; } \\
\text { - } 3(0.14 \%) \text { - death; } \\
\text { - } 1(0.05 \%) \text { - DI }\end{array}$ \\
\hline $\begin{array}{l}\text { operative and } \\
\text { bloodless limb } \\
\text { lengthening }\end{array}$ & 15 & \begin{tabular}{|l} 
Number of cases: $1829,697(38.11 \%)$ AE found, among them: \\
$\cdot 295(16.13 \%)-$ CC \\
$\cdot 215(11.76 \%)-$ WTI \\
$\cdot 140(7.65 \%)-$ ND \\
$\cdot 32(1.75 \%)-$ WC \\
$\cdot 10(0.55 \%)-$ D/S \\
$\cdot 4(0.22 \%)-$ WB \\
$\cdot 1(0.05 \%)-$ VD
\end{tabular} & $\begin{array}{l}\text { Number of cases: } 1829 \\
4(0.22 \%) \text { SAE found: } \\
\text { - } 4(0.22 \%) \text { - osteomyelitis }\end{array}$ \\
\hline $\begin{array}{l}\text { correction of } \\
\text { deformities and } \\
\text { management of } \\
\text { long bone defects } \\
\text { without bone } \\
\text { grafts }\end{array}$ & 16 & $\begin{aligned} \text { Number of cases: } 2242,588(26.23 \%) \text { AE found, among them: } \\
\text { • } 258(11.51 \%)-\text { WTI } \\
\cdot 152(6.78 \%)-\text { CC } \\
\cdot 111(4.95 \%)-\text { ND } \\
\cdot 31(1.38 \%)-\text { WC } \\
\cdot 18(0.80 \%)-\text { WB } \\
\cdot 11(0.50 \%)-\text { dermatitis } \\
\cdot 7(0.31 \%)-\text { VD }\end{aligned}$ & $\begin{array}{l}\text { Number of cases: } 2242,15 \\
(0.67 \%) \text { SAE found, among } \\
\text { them: } \\
\text { - } 14(0.62 \%) \text { - osteomyelitis; } \\
\text { - } 1(0.05 \%) \text { - death }\end{array}$ \\
\hline $\begin{array}{l}\text { compression } \\
\text { arthrodesis of } \\
\text { large joints or } \\
\text { elimination of } \\
\text { stiff contractures }\end{array}$ & 3 & $\begin{aligned} \text { Number of cases: } 148,24(16.22 \%) \text { AE found, among them: } \\
\cdot 18(12.16 \%)-\text { WTI } \\
\cdot 3(2.03 \%)-\text { WB } \\
\cdot 2(1.35 \%)-\text { ND } \\
\cdot 1(0.68 \%)-\text { CC }\end{aligned}$ & $\begin{array}{l}\text { Number of cases: } 148 \text {, } \\
\text { one }(0.68 \%) \text { SAE found: } \\
\text { - } 1(0.68 \%)-\text { DI }\end{array}$ \\
\hline
\end{tabular}

Notes: Abr. adverse events $(A E)$ and severe adverse events $(S A E)$ : D/S - dislocation, subluxation of joints; WTI - wire tract inflammation; DI - deep infection; CC - contractures; ND - neurological disorders; WC - wire cutting out of soft tissues; WB - wire/pin breakage; $\mathrm{VD}$ - vascular damage. * - difference in the number of cases is due to the fact that in a part of the works there is an analysis of only severe complications 
Table 3

Summarized data on numbers of adverse events and severe adverse effects in clinical use of the Ilizarov apparatus for external fixation for treating various musculoskeletal pathology

\begin{tabular}{|c|c|c|}
\hline Adverse events $(A E)$ & Number & $\begin{array}{c}\text { \% from the total of cases } \\
{[5 \div 95 \%-\mathrm{CI}]}\end{array}$ \\
\hline $\begin{array}{l}\text { wire tract inflammation } \\
\text { contractures } \\
\text { neurological disorders } \\
\text { cutting of wires out of soft tissues } \\
\text { wire/pin breakage } \\
\text { vascular damage } \\
\text { dermatitis } \\
\text { dislocation, subluxation of joints } \\
\quad \text { Total (number of cases: 6224) }\end{array}$ & $\begin{array}{c}856 \\
535 \\
262 \\
157 \\
35 \\
12 \\
11 \\
10 \\
1878\end{array}$ & $\begin{array}{c}13,75[12,91 \div 14,62] \\
8,60[7,92 \div 9,31] \\
4,21[3,73 \div 4,72] \\
2,52[2,15 \div 2,92] \\
0,56[0,39 \div 0,76] \\
0,19[0,10 \div 0,31] \\
0,18[0,09 \div 0,30] \\
0,16[0,08 \div 0,27] \\
\mathbf{3 0 , 1 7}[\mathbf{2 9 , 0 4 \div 3 1 , 3 2 ]}\end{array}$ \\
\hline Severe adverse effects $(S A E)$ & & \\
\hline Total (number of cases: $6274^{*}$ ) & $\begin{array}{c}59 \\
4 \\
2 \\
65\end{array}$ & $\begin{array}{c}0,94[0,72 \div 1,19] \\
0,06[0,01 \div 0,14] \\
0,03[0 \div 0,09] \\
\mathbf{1 , 0 4}[\mathbf{0 , 8 0} \div \mathbf{1}, \mathbf{3 1}]\end{array}$ \\
\hline
\end{tabular}

* - difference in the number of cases is due to the fact that in a part of the works there is an analysis of only severe complications

Adverse events analysis $(A E)$ According to the results of the literature assessed by the study, the $A E$ rate by using the Ilizarov apparatus of external fixation (in various configurations) was $30.17 \%(5 \div 95 \% \mathrm{CI}$ : $29.04 \div 31.32 \%$ ). Assessing the interconnection of the AEs with the use of the Ilizarov apparatus listed above, only one event was rated as "no relationship". It is dislocation and subluxation of the joints, which develops in the patients violating treatment regimen and neglecting the requirements of osteosynthesis.

The relationship of the remaining cases with the functioning of the apparatus was evaluated by us as reliable, probable and likely.

Cases of wire tract soft tissue inflammation, cutting of wires through soft tissue, vascular damage, wires/ pins breakage have a reliable relationship with the use of the product and are qualified as adverse effects $(A D E)$. Obviously, all these events are the result of the contact of the elements of the apparatus with tissues and organs of the body. All these AE arise due to errors in the Ilizarov apparatus maintenance (improper sterilization preparation, insufficient treatment of the parts after the apparatus was applied while changing dressings, non-observance of personal hygiene, etc.). Clinical experience presented in the sources studied shows that all $A E$ s of this group can be managed without dismantling the device in almost $100 \%$ of cases by using antibiotics and/or wire reinsertion. All the authors of the works analyzed by us pointed out that these events did not affect the final result of treatment. If the inflammatory process in the tissues surrounding the wires remains untreated, according to generalized experience, the process may aggravate and result in osteomyelitis (see $S A E$ analysis).

Cases of dermatitis are probably associated with the product use, as it can be assumed that the cause of this event could be a lack of proper skin care, disease recurrence or predisposition to it.

Contractures and neurological disorders have a likely relationship with the use of the product; therefore, qualifying them as $A D E$ is not entirely correct. Clinical experience shows that these events can indeed be the result of the injuries to the muscles and/or nerves with the parts of the product in contact with them. However, these cases mostly happen due to inadequate clinical post-operative care of the patients with the Ilizarov apparatus on (inadequate pharmacotherapy, lack of exercise therapy, physiotherapy, etc.). They can be completely corrected applying appropriate procedures or proper medication. These events, when corrected before apparatus dismantling, as shown by overall experience, do not affect the outcome of treatment either.

Thus, if we exclude from the general statistics those $A E$, the relationship of which with the performance of the product is not obvious (dermatitis, contractures, neurological disorders, dislocations and subluxations), we can calculate the number of $A D E$ resulting from the impact of the Ilizarov apparatus: 1060 cases of $A D E$ out of the total 6,224 which is $17.03 \%$ (5 $\div 95$ \% CI: $16.11 \div 17.97 \%)$. 
Severe adverse effects analysis (SAE) According to the results of the study, the SAE rates by application of the Ilizarov apparatus (in various configurations) was $1.04 \%(5 \div 95 \% \mathrm{CI}: 0.80 \div 1.31 \%)$.

Lethal outcomes were associated with cardiovascular diseases (2 cases), exacerbation of liver diseases (one case), one death happened as a result of acute massive blood loss in a patient with a gunshot injury. Obviously, all the SAEs listed were not associated with the use of the Ilizarov apparatus but with concomitant diseases, or due to the severity of the primary injury.

Cases of osteomyelitis and deep infection of tissues, as shown by the experience of the clinical use of the Ilizarov external fixation apparatus, develop due to the lack of treatment of soft tissue inflammation in the area of the wires. Therefore, it is not correct to qualify cases of osteomyelitis and deep infection of tissues as a severe adverse effect of the product itself $(S A D E)$.

To further evaluate the safety of the Ilizarov apparatus, we analyzed sources containing research data that compared the clinical safety of the Ilizarov apparatus of external fixation with other methods and technologies used in orthopedics and traumatology.
A total of 12 comparative studies were found.

Incidence of adverse events and osteomyelitis with the use of the Ilizarov external fixation apparatus did not statistically significantly differ from the compared methods in 10 studies.

Statistically significant differences were found between several safety indicators in the use of transosseous osteosynthesis technologies implemented with the Ilizarov apparatus in two papers. In particular, the authors of one report [115] observed a lower incidence of deep infection by using the Ilizarov apparatus relative to the monolateral fixator. In another study [73], it was found that the rate of unplanned hardware removal of the Ilizarov apparatus elements was significantly lower than that of internal fixators.

Thus, the safety analysis of the Ilizarov apparatus for external fixation used in various configuration showed the following quantitative characteristics:

- rate of adverse events $(A E): 30.17(5 \div 95 \%$ CI: $29.04 \div 31.32 \%$ );

- rate of adverse effects of the product $(A D E)$ : $17.03 \%(5 \div 95 \%$ CI: $16.11 \div 17.97 \%)$;

- rate of severe adverse effects (SAE): $1.04 \%$ $(5 \div 95 \%$ CI: $0.80 \div 1.31 \%$ )

\section{DISCUSSION}

The analysis of the clinical data shows high efficiency of transosseous osteosynthesis technology, implemented through the use of the Ilizarov external fixation apparatus for solving a wide range of clinical problems in the field of traumatology and orthopedics. According to the results of the study, the high clinical efficacy of treatment was confirmed both in regard to the total of cases treated (about $95 \%$ of positive outcomes) and in separate nosological groups (not lower than $90 \%$ of positive outcomes). Clinical data prove that the Ilizarov apparatus provides all the qualities claimed: reduction and fixation in open and closed bone fracture repair as well as compression and distraction forces on bone fragments for various orthopedic tasks.

Comparative studies demonstrate that the effectiveness of treating patients with an orthopedic diseases and injuries using the Ilizarov apparatus for external fixation is not lower than with other methods, and according to certain parameters the product has significant (statistically significant) effectiveness in separate clinical groups, including the economic factor.

The rate of treatment failures using the Ilizarov apparatus can be estimated at 4 to $5 \%$ according to the analysis of available sources. Failures are associated with relapses of pathologies. These are severe injuries and bone infection (mainly osteomyelitis and infected fractures), congenital defects and systemic abnormalities. Given these circumstances, we can consider this amount of poor results in patients with an orthopedic diseases and injuries treated with the Ilizarov apparatus for external fixation acceptable.

Given the available safety data of the technology of transosseous osteosynthesis, implemented through the use of the Ilizarov apparatus for external fixation (in various configurations), we can conclude that the incidence of $A E$ and $S A E$ recorded according to the analysis can be considered acceptable due to the following factors:

- among all $A E s$, the incidence of product adverse effect $(A D E)$ is $17.03 \%(5 \div 95 \% \mathrm{CI}: 16.11 \div 17.97 \%)$; 
- all adverse events are predictable, due to the long experience accumulated in using the Ilizarov apparatus;

- most of the $A E \mathrm{~s}$, if they are timely eliminated, practically do not affect the final result of treatment;

- considerable experience has been accumulated in prevention and elimination of all $A E \mathrm{~s}$, most $A E \mathrm{~s}$ are stopped without dismantling the device [132, 133];

-incidence of AE decreases with the accumulation of both individual and collective experience in using the Ilizarov apparatus for external fixation [134, 135].

Product safety can be rated as very high. So, among all $A E$ cases, the percentage of wire/half-pin breakage (the only $A E$ that can be associated with safety) was only $0.56 \%(5 \div 95 \%$ CI: $0.39 \div 0.76 \%)$. None of the analyzed sources indicate that the parts used to assemble the Ilizarov apparatus for external fixation were unstable to sterilization.

\section{CONCLUSION}

Thus, the analysis and evaluation of the data on the

allows us to conclude that its efficacy is quite high; the application of the Ilizarov apparatus for external fixation emerging clinical risks are acceptable and can be eliminated.

\section{REFERENCES}

1. Gubin A., Borzunov D., Malkova T. Ilizarov method for bone lengthening and defect management review of contemporary literature. Bull. Hosp. Jt. Dis., 2016, vol. 74, no. 2, pp.145-154.

2. Yin P., Ji Q., Li T., Li J., Li Z., Liu J., Wang G., Wang S., Zhang L., Mao Z., Tang P. A systematic review and meta-analysis of Ilizarov methods in the treatment of infected nonunion of tibia and femur. PLoS One, 2015, vol. 10, no. 11, pp. e0141973. DOI: 10.1371/journal.pone.0141973.

3. Gubin A.V., Borzunov D.Y., Malkova T.A. The Ilizarov paradigm: thirty years with the Ilizarov method, current concerns and future research. Int. Orthop., 2013, vol. 37, no. 8, pp. 1533-1539. DOI: 10.1007/s00264-013-1935-0.

4. Gulabi D., Erdem M., Cecen G.S., Avci C.C., Saglam N., Saglam F. Ilizarov fixator combined with an intramedullary nail for tibial nonunions with bone loss: is it effective? Clin. Orthop. Relat. Res., 2014, vol. 472, no. 12, pp. 3892-3901. DOI: 10.1007/s11999014-3640-8.

5. Azzam W., El-Sayed M. Ilizarov distraction osteogenesis over the preexisting nail for treatment of nonunited femurs with significant shortening. Eur. J. Orthop. Surg. Traumatol., 2016, vol. 26, no. 3, pp. 319-328. DOI: 10.1007/s00590-016-1740-8.

6. Sabharwal S., Green S., McCarthy J., Hamdy R.C. What's new in limb lengthening and deformity correction. I. Bone Joint Surg. Am., 2011, vol. 93, no. 2, pp. 213-221. DOI: 10.2106/JBJS.J.01420.

7. Sabharwal S., Nelson S.C., Sontich J.K. What's new in limb lengthening and deformity correction. J. Bone Joint Surg. Am., 2015, vol. 97, no. 16, pp. 1375-1384. DOI: 10.2106/JBJS.O.00298.

8. Popkov D., Lascombes P., Journeau P., Popkov A. Current approaches to flexible intramedullary nailing for bone lengthening in children. J. Child. Orthop., 2016, vol. 10, no. 6, pp. 499-509.

9. Pobloth A.M., Schell H., Petersen A., Beierlein K., Kleber C., Schmidt-Bleek K., Duda G.N. Tubular open-porous $\beta$-tricalcium phosphate polycaprolactone scaffolds as guiding structure for segmental bone defect regeneration in a novel sheep model. J. Tissue Eng. Regen. Med., 2018, vol. 12, no. 4, pp. 897-911. DOI: 10.1002/term.2446.

10.Polyzois V.D., Stathopoulos I.P., Lampropoulou-Adamidou K., Vasiliadis E.S., Vlamis J., Pneumaticos S.G. Strategies for managing bone defects of the lower extremity. Clin. Podiatr. Med. Surg., 2014, vol. 31, no. 4, pp. 577-584. DOI: 10.1016/j.cpm.2014.06.008.

11.Paley D. Problems, obstacles, and complications of limb lengthening by the Ilizarov technique. Clin. Orthop. Relat. Res., 1990 , no. 250, pp. 81-104.

12.Eralp L., Bilen F.E., Rozbruch S.R., Kocaoglu M., Hammoudi A.I. External fixation reconstruction of the residual problems of benign bone tumours. Strategies Trauma Limb Reconstr., 2016, vol. 11, no. 1, pp. 37-49. DOI: 10.1007/s11751-016-0244-8.

13.Moraal J.M., Elzinga-Plomp A., Jongmans M.J., Roermund P.M., Flikweert P.E., Castelein R.M., Sinnema G. Long-term psychosocial functioning after Ilizarov limb lengthening during childhood. Acta Orthop., 2009, vol. 80, no. 6, pp. 704-710. DOI: $10.3109 / 17453670903473024$.

14.Novikov K.I., Subramanyam K.N., Muradisinov S.O., Novikova O.S., Kolesnikova E.S. Cosmetic lower limb lengthening by Ilizarov apparatus: what are the risks? Clin. Orthop. Relat. Res., 2014, vol. 472, no. 11, pp. 3549-3556. DOI: 10.1007/s11999-0143782-8.

15.Barker K.L., Lamb S.E., Simpson H.R. Recovery of muscle strength and power after limb-lengthening surgery. Arch. Phys. Med. Rehabil., 2010, vol. 91, no. 3, pp. 384-388. DOI: 10.1016/j.apmr.2009.11.014.

16.Sun X.T., Easwar T.R., Manesh S., Ryu J.H., Song S.H., Kim S.J., Song H.R. Complications and outcome of tibial lengthening using the Ilizarov method with or without a supplementary intramedullary nail: a case-matched comparative study. J. Bone Joint Surg. Br., 2011, vol. 93, no. 6, pp. 782-787. DOI: 10.1302/0301-620X.93B6.25521.

17.Bernstein M., Fragomen A.T., Sabharwal S., Barclay J., Rozbruch S.R. Does Integrated Fixation Provide Benefit in the Reconstruction of Posttraumatic Tibial Bone Defects? Clin. Orthop. Relat. Res., 2015, vol. 473, no. 10, pp. 3143-3153. DOI: 10.1007/s11999-0154326-6.

18.Ruette P., Lammens J. Humeral lengthening by distraction osteogenesis: a safe procedure? Acta Orthop Belg., 2013, vol. 79, no. 6, pp. 636-642.

19.Hosny G.A. Humeral lengthening and deformity correction. J. Child. Orthop., 2016, vol. 10, no. 6, pp. 585-592. DOI: 10.1007/ s11832-016-0789-6. 
20.Jochymek J., Gal P. Evaluation of bone healing in femurs lengthened via the gradual distraction method. Biomed. Pap. Med. Fac. Univ. Palacky Olomouc. Czech Repub., 2007, vol. 151, no. 1, pp. 137-141.

21.Sampaio F.M., Marçal L.P., Dos Reis D.G., Kasuo A.W., Fraga C.E., De Moraes F.B. Clinical evaluation of patients submitted to osteogenic distraction in the lower limb at a university hospital. Rev. Bras. Ortop., 2016, vol. 51, no. 5, pp. 521-526. DOI: 10.1016/j. rboe.2016.08.010.

22.Farr S., Mindler G., Ganger R., Girsch W. Bone lengthening in the pediatric upper extremity. J. Bone Joint Surg. Am., 2016, vol. 98, no. 17, pp. 1490-1503. DOI: 10.2106/JBJS.16.00007.

23.Gubin A.V., Borzunov D.Y., Malkova T.A., Belokon N.S. Activities of a large limb lengthening and reconstruction center in the $21^{\text {st }}$ century. J. Limb Lengthen. Reconstr., 2018, vol. 4, no. 1, pp. 6-10. DOI: DOI: 10.4103/jllr.jllr_26_17.

24.Gubin A.V., Borzunov D.Y., Marchenkova L.O., Malkova T.A., Smirnova I.L. Contribution of G.A. Ilizarov to bone reconstruction: historical achievements and state of the art. Strategies Trauma Limb Reconstr., 2016, vol. 11, no. 3, pp. 145-152. DOI: 10.1007/ s11751-016-0261-7.

25.Aranovich A.M., Dindiberia E.V., Klimov O.V., Novikov K.I. Oshibki i oslozhneniia pri udlinenii goleni u bolnykh akhondroplaziei [Errors and complications when the leg lengthening in patients with achondroplasia]. Travmatologiia i Ortopediia Rossii, 2005, no. 1, pp. 36-37. (in Russian)

26.Aranovich A.M., Klimov O.V., Novikov K.I. Reabilitatsiia patsientov s nizkim rostom [Rehabilitation of low-height patients]. Genij Ortopedii, 2011, no. 2, pp. 20-25. (in Russian)

27.Balaev P.I., Balaev I.I., Borzunov D.Y. Chreskostnyi kompressionno-distraktsionnyi osteosintez po Ilizarovu v ortopedicheskoi reabilitatsii bolnykh s pervichnymi opukholiami kostei goleni [Transosseous compression-distraction osteosynthesis by Ilizarov in orthopaedic rehabilitation of patients with primary tumors of leg bones]. Genij Ortopedii, 2011, no. 2, pp. 84-90. (in Russian)

28. Balaev P.I., Borzunov D.Y. Metod chreskostnogo osteosinteza po Ilizarovu v lechenii bolnykh s gigantokletochnymi opukholiami kostei goleni [Transosseous osteosynthesis method according to Ilizarov in treating patients with leg bone giant-cell tumors]. Zabaikalskii Meditsinskii Vestnik, 2016, no. 4, pp. 48-53. (in Russian)

29.Beidick O.V., Nikolenko V.N., Levchenko K.K., Loukpanova T.N., Aristova I.S., Sakkalla Kh.M.F. Anatomo-funktsionalnyi podkhod k lecheniiu bolnykh s vrozhdennoi varusnoi deformatsiei golenei [An anatomic-and-functional approach to treatment of patients with the congenital varus deformity of the legs]. Genij Ortopedii, 2008, no. 1, pp. 37-40. (in Russian)

30.Bondarenko A.V., Pechenin S.A. Apparat Ilizarova v lechenii otkrytykh perelomov kostei goleni s defektom miagkikh tkanei po perednevnutrennei poverkhnosti [The Ilizarov apparatus in treatment of open leg bone fractures with soft-tissue defects along the anterio-inferior surface]. Genij Ortopedii, 2003, no. 3, pp. 43-45. (in Russian)

31.Bondarenko A.V., Pechenin S.A. Ispolzovanie apparata Ilizarova v lechenii ognestrelnykh vysokoenergeticheskikh ranenii bedra [Use of the Ilizarov fixator for treatment of gunshot high-energy femoral injuries]. Genij Ortopedii, 2004, no. 1, pp. 123-125. (in Russian)

32.Bondarenko A.V., Smaznev K.V., Pechenin S.A. Chreskostnyi osteosintez povrezhdenii taza i vertluzhnoi vpadiny pri politravme [Transosseus osteosynthesis for pelvic and acetabular injuries in case of polytrauma]. Genij Ortopedii, 2006, no. 3, pp. 45-51. (in Russian)

33.Borzunov D.Y. Zameshchenie defektov dlinnykh kostei polilokalnym udlineniem otlomkov [Filling long bone defects by polylocal fragmental lengthening]. Travmatologiia i Ortopediia Rossii, 2006, no. 4, pp. 24-29. (in Russian)

34. Borzunov D.Y., Mokhovikov D.S. Osobennosti chreskostnogo osteosinteza pri zameshchenii postrezektsionnykh defektov trubchatykh kostei kisti [The features of transosseous osteosynthesis for filling the post-resection defects of hand tubular bones]. Genij Ortopedii, 2009, no. 2, pp. 34-39. (in Russian)

35.Bouravtsov P.P., Gorevanov E.A., Muradisinov M.S. Oshibki, oslozhneniia i ikh profilaktika pri operativnom lechenii vyvikha nadkolennika [Errors, complications and their prevention for the surgical treatment of patellar dislocation]. Genij Ortopedii, 2006, no. 2, pp. 86-88. (in Russian)

36.Garbuz I.F., Andriesh N.G., Mazur V.G., Panasenko R.D. Vneochagovyi osteosintez apparatom ilizarova pri perelome kostei goleni $\mathrm{u}$ detei [Extrafocal osteosynthesis with the Ilizarov fixator for a leg bone fracture in children]. Materialy iubil. vseros. nauch.-prakt. konf. «Aktualnye voprosy travmatologii i ortopedii», posviashch. 100-letiiu so dnia osnovaniia ros. nauch.-issled. in-ta travmatologii i ortopedii im. R.R. Vredena [Proc. Jubil. All-Russian Scientific-practical Conference "Current problems of Traumatology and Orthopaedics", devoted to 100th anniversary of the founding Russian Vreden Scientific Research Institute of Traumatology and Orthopaedics]. Travmatologiia i Ortopediia Rossii, 2006, no. 2, pp. 69. (in Russian)

37.Gorbunov E.V. Metodiki chreskostnogo osteosinteza pri lechenii bolnykh s zakrytymi perelomami loktevogo otrostka [Transosseous osteosynthesis techniques in management of patients with closed olecranon fractures]. Genij Ortopedii, 2009, no. 4, pp. $104-109$. (in Russian)

38.Gorevanov E.A., Popkov D.A., Muradisinov S.O., Kolchev V.O. Oshibki i oslozhneniia pri bilokalnom monosegmentarnom distraktsionnom osteosinteze vrozhdenno ukorochennoi goleni [Errors and complications of bifocal monosegmental distraction osteosynthesis for congenitally shortened leg]. Genij Ortopedii, 2003, no. 3, pp. 33-38. (in Russian)

39.Gofman F.F., Muradisinov S.O., Novikov K.I., Klimov O.V. Rezultaty lecheniia patsientov s posledstviiami gematogennogo osteomielita plechevoi kosti s ispolzovaniem novykh metodik chreskostnogo osteosinteza [Treatment results of patients with humeral hematogenous osteomyelitis sequelae using new techniques of transosseous osteosynthesis]. Genij Ortopedii, 2009, no. 1, pp. 80-83. (in Russian)

40.Danilkin M.Yu. Udlinenie trubchatykh kostei kisti apparatom naruzhnoi fiksatsii FGU «RNTs «VTO» im. akad. G.A. Ilizarova» [Lengthening of hand tubular bones with the FSI «RISC «RTO» external fixator]. Genij Ortopedii, 2009, no. 2, pp. 22-27. (in Russian)

41.Dzhafarov A., Tan I., Giul'shen M., Ali-Zade Ch. Analiz rezultatov lecheniia perelomov plato bolshebertsovoi kosti apparatom Ilizarova [Analysis of the results of treating tibial plateau fractures with the Ilizarov fixator]. Genij Ortopedii, 2015, no. 1, pp. 1722. (in Russian)

42.Djachkov A.N., Soldatov Yu.P., Stolbikov S.A., Zverev E.S. Sravnitelnyi analiz oshibok i oslozhnenii pri lechenii bolnykh s 
zakrytymi perelomami kostei goleni konservativnymi i operativnymi metodami v usloviiakh gorodskoi bolnitsy i mediko-sanitarnoi chasti [A comparative analysis of errors and complications when treating patients with closed leg bone fractures using conservative and surgical methods under the conditions of the city hospital and medical unit]. Meditsinskaia Nauka i Obrazovanie Urala, 2011, no. 2, pp. 127-130. (in Russian)

43.Zyrianov S.S., Soldatov Yu.P., Zyrianov S.Ya. Operativnoe lechenie patsientov s posttravmaticheskim ploskostopiem s primeneniem apparata Ilizarova [Surgical treatment of patients with posttraumatic flat foot using the Ilizarov fixator]. Genij Ortopedii, 2011, no. 3, pp. 38-41. (in Russian)

44.Karasev E.A. Operativnoe lechenie bolnykh s zakrytymi perelomami nadkolennika s primeneniem artroskopicheskikh tekhnologii [Surgical treatment of patients with closed patellar fractures using arthroscopic technologies]. Genij Ortopedii, 2011, no. 1, pp. 145151. (in Russian)

45.Kliushin N.M., Shliakhov V.I., Zlobin A.V., Burnashov S.I., Chakushin B.E., Ababkov Yu.V., Mikhailov A.G. Chreskostnyi osteosintez pri lechenii osteomielita dlinnykh kostei verkhnei konechnosti [Transosseous osteosynthesis in treatment of osteomyelitis of upper limb long bones]. Genij Ortopedii, 2010, no. 4, pp. 45-50. (in Russian)

46.Kozhevnikov V.V., Voronchikhin E.V., Grigoricheva L.G., Radimova Zh.N. Primenenie apparata Ilizarova v lechenii detei s retsidiviruiushchei vrozhdennoi kosolapostiu [The Ilizarov fixator use in the treatment of children with recurrent congenital clubfoot]. Ortopediia, Travmatologiia i Vosstanovitelnaia Khirurgiia Detskogo Vozrasta, 2016, no. 1, pp. 5-10. (in Russian)

47. Lapynin A.I., Popova L.A. Otsenka otdalennykh rezultatov lecheniia bolnykh khronicheskim osteomielitom kostei nizhnikh konechnostei s nalichiem kostnykh polostei metodom upravliaemogo chreskostnogo osteosinteza [The evaluation of long-term results of treating patients with chronic osteomyelitis of the lower limb bones with presenting bone cavities using the method of controlled transosseous osteosynthesis]. Travmatologiia $i$ Ortopediia Rossii, 2011, no. 4, pp. 53-61. (in Russian)

48.Larionov A.A., Makarov M.L., Odinochenko N.G., Antonova L.N., Tyrnov I.S. Chreskostnyi osteosintez po Ilizarovu pri perelomakh kostei goleni i ikh posledstviiakh [Transosseous osteosynthesis according to Ilizarov for leg bone fractures and their consequences]. Tez. kongr. «Meditsina chrezvychainykh situatsii. Sovremennye tekhnologii v travmatologii i ortopedii» [Proc. Congr. "Emergency Medicine. Current Technologies in Traumatology and Orthopaedics”]. Kafedra Travmatologii i Ortopedii, 2016, spetsvypusk, pp. 4950. (in Russian)

49.Martel' I.I., Darvin E.O. Lechenie zakrytykh perelomov kliuchitsy razlichnymi variantami osteosinteza [Treatment of closed clavicular fractures using various osteosynthesis variants]. Genij Ortopedii, 2011, no. 4, pp. 5-8. (in Russian)

50.Martel' I.I., Karasev A.G., Boichuk S.P., Karasev E.A., Badalov Kh.T. Chreskostnyi osteosintez apparatom Ilizarova pri povrezhdeniiakh akromialnogo kontsa kliuchitsy [Transosseous osteosynthesis with the Ilizarov fixator for injuries of the acromial end of the clavicle]. Genij Ortopedii, 2013, no. 3, pp. 5-8. (in Russian)

51.Mitrofanov A.I., Borzunov D.Yu. Rezultaty lecheniia patsientov s aktivnymi solitarnymi kostnymi kistami s primeneniem chreskostnogo osteosinteza [Results of treatment in patients with active solitary bone cysts using transosseous osteosynthesis]. Genij Ortopedii, 2010, no. 2, pp. 55-59. (in Russian)

52.Nazarov F.N., Linnik S.A. Rol osteosinteza metodom ilizarova pri sochetannykh i mnozhestvennykh travmakh nizhnikh konechnostei [The role of osteosynthesis by the Ilizarov method for concomitant and multiple injuries of the lower limbs]. Vestnik Poslediplomnogo Obrazovaniia v Sfere Zdravookhraneniia, 2014, no. 2, pp. 41-46. (in Russian)

53.Neretin A.S., Ivanov G.P., Danilkin M.Yu. Udlinenie kostei perednego otdela stopy metodom chreskostnogo osteosinteza po Ilizarovu [Lengthening of forefoot bones by transosseous osteosynthesis method according to Ilizarov]. Genij Ortopedii, 2011 , no. 2, pp. 54-59. (in Russian)

54.Novikov K.I., Kolesnikova E.S., Muradisinov S.O., Dyachkova G.V., Novikova O.S., Diachkov K.A. Udlinenie goleni v proksimalnoi treti metodom chreskostnogo osteosinteza po Ilizarovu [Leg lengthening in the proximal third using transosseous osteosynthesis method according to Ilizarov]. Genij Ortopedii, 2014, no. 3, pp. 19-23. (in Russian)

55.Pankov I.O., Emelin A.L., Nigmatullin V.R., Salikhov R.Z. Chreskostnyi osteosintez pri supinatsionno-inversionnykh perelomakh distalnogo sustavnogo otdela kostei goleni [Transosseous osteosynthesis for supination-inversion fractures of the distal articular part of leg bones]. Prakticheskaia Meditsina, 2013, vol. 2, no. 1-2, pp. 114-118. (in Russian)

56.Pankov I.O., Riabchikov I.V., Nigmatullin V.R. Nash opyt lecheniia patsientov s perelomami oblasti kolennogo sustava [Our experience of treating patients with the knee fractures]. Sovremennye Problemy Nauki i Obrazovaniia, 2012, no. 5. (in Russian) Available at: http://science-education.ru/ru/article/view?id=7019 (accessed 09.09.2018).

57.Pankov I.O., Riabchikov I.V., Nigmatullin V.R. Chreskostnyi osteosintez pri perelomakh i perelomo-vyvikhakh tarannoi kosti [Transosseous osteosynthesis for fractures and fracture-dislocations of the talus]. Prakticheskaia Meditsina, 2012, no. 8-2 (64), pp. 135-139. (in Russian)

58.Sikilinda V.D., Alabut A.V., Dubinskii A.V. Taktika i analiz rezultatov lecheniia bolnykh s kostnymi defektami [The tactics and analysis of the results of treating patients with bone defects]. Kubanskii Nauchnyi Meditsinskii Vestnik, 2009, no. 2, pp. 34-38. (in Russian)

59.Sysenko Yu.M. Osobennosti chreskostnogo osteosinteza po Ilizarovu pri lechenii mnozhestvennykh perelomov u detei i podrostkov [Peculiarities of transosseous osteosynthesis according to Ilizarov during the treatment of multiple fractures in children and adolescents]. Genij Ortopedii, 2003, no. 3, pp. 5-9. (in Russian)

60.Sysenko Yu.M., Bunov D.V. Lechenie bolnykh so slozhnymi perelomami golenostopnogo sustava metodom chreskostnogo osteosinteza po Ilizarovu [Treatment of patients with compound fractures of the ankle by the transosseous osteosynthesis method according to Ilizarov]. Genij Ortopedii, 2003, no. 3, pp. 29-32. (in Russian)

61.Sysenko Y.M., Nasyrov M.Z. Travmy epifizarnogo rostkovogo khriashcha distalnogo otdela goleni i ikh lechenie metodom chreskostnogo osteosinteza [The injuries of the epiphyseal growth cartilage of the distal leg and their treatment by transosseous osteosynthesis technique]. Genij Ortopedii, 2004, no. 1, pp. 107-113. (in Russian)

62.Sysenko Y.M., Smelyshev K.N. Vozmozhnosti chreskostnogo osteosinteza pri lechenii bolnykh s vnutrisustavnymi perelomami distalnogo epimetafiza bolshebertsovoi kosti [Possibilities of transosseous osteosynthesis use in treatment of patients with intraarticular fractures of the distal tibial epimetaphysis]. Genij Ortopedii, 2003, no. 2, pp. 51-53. (in Russian) 
63.Tropin V.I., Buravtsov P.P., Biriukova M.Iu., Chertishchev A.A., Tropin D.V. Operativnoe lechenie patsientov s gonartrozom i varusnoi deformatsiei kolennogo sustava s primeneniem apparata Ilizarova [Surgical treatment of patients with gonarthrosis and varus deformity of the knee using the Ilizarov fixator]. Genij Ortopedii, 2016, no. 1, pp. 70-74. (in Russian)

64.Khoudzhanov A.A. Blizhaishie i otdalennye rezultaty lecheniia vrozhdennoi kosolaposti u detei s primeneniem apparata Ilizarova [The immediate and long-term results of treatment for congenital clubfoot in children using the Ilizarov fixator]. Genij Ortopedii, 2004, no. 4, pp. 49-52. (in Russian)

65.Chibirov G.M., Soldatov Y.P. Operativnoe lechenie bolnykh s posledstviiami travm loktevogo sustava s primeneniem apparata Ilizarova [Surgical treatment of patients with the elbow injury consequences using the Ilizarov fixator]. Sovremennye Problemy Nauki i Obrazovaniia, 2015, no. 5. (in Russian) Available at: http://science-education.ru/ru/article/view?id=7019 (accessed 21.09.2018).

66.Shved S.I., Karasev A.G. Chreskostnyi osteosintez po Ilizarovu pri lechenii bolnykh s perelomami oboikh beder [Transosseous osteosynthesis according to Ilizarov for treatment of patients with bilateral femoral fractures]. Genij Ortopedii, 2002, no. 2, pp. 1518. (in Russian)

67.Shved S.I., Karasev A.G., Dolganova T.I., Sveshnikov A.A. Lechenie bolnykh s mnozhestvennymi perelomami kostei nizhnikh konechnostei metodom chreskostnogo osteosinteza po Ilizarovu [Treatment of patients with multiple fractures of lower limb bones using the method of transosseous osteosynthesis according to Ilizarov]. Genij Ortopedii, 2006, no. 4, pp. 75-78. (in Russian)

68.Shevtsov V.I., Ismailov G.R., Kozmina T.Y., Znamenskaia M.G., Danilkin M.Y. Vozmozhnosti chreskostnogo osteosinteza pri lechenii bolnykh s priobretennoi patologiei kisti [Transosseous osteosynthesis potentials in treatment of patients with the hand acquired pathology]. Genij Ortopedii, 2002, no. 1, pp. 19-23. (in Russian)

69.Shevtsov V.I., Makushin V.D., Kuftyrev L.M. Defekty kostei nizhnei konechnosti [Defects of the lower limb bones]. Kurgan, Zaurale, 1996, 504 p. (in Russian)

70.Shchukin A.A., Aranovich A.M., Popkov A.V., Popkov D.A. Otsenka rezultatov udlineniia nizhnikh konechnostei u bolnykh s sistemnymi zabolevaniiami skeleta, soprovozhdaiushchimisia patologicheski nizkim rostom [Evaluation of the results of lower limb lengthening in patients with systemic skeletal diseases accompanied by pathologically short stature]. Genij Ortopedii, 2014, no. 2, pp. 44-51. (in Russian)

71.Iamshchikov O.N., Markov D.A., Emelianov S.A. Primenenie chreskostnogo osteosinteza apparatami vneshnei fiksatsii pri perelomakh bedrennykh kostei v sovremennykh usloviiakh [Current use of transosseous osteosynthesis with external fixators for femoral fractures]. Saratovskii Nauchno-Meditsinskii Zhurnal, 2014, vol. 10, no. 4, pp. 645-648. (in Russian)

72.Atar D., Lehman W.B., Grant A.D., Strongwater A., Frankel V., Golyakhovsky V. Treatment of complex limb deformities in children with the Ilizarov technique. Orthopedics, 1991, vol. 14, no. 9, pp. 961-967.

73.Bacon S., Smith W.R., Morgan S.J., Hasenboehler E., Philips G., Williams A., Ziran B.H., Stahel P.F. A retrospective analysis of comminuted intra-articular fractures of the tibial plafond: Open reduction and internal fixation versus external Ilizarov fixation. Injury, 2008, vol. 39, no. 2, pp. 196-202. DOI: 10.1016/j.injury.2007.09.003.

74.Baschera D., Kingwell D., Wren M., Zellweger R. A holistic perspective of patients' lives post-Ilizarov external fixation. ANZ J. Surg., 2014, vol. 84, no. 10, pp. 776-780. DOI: 10.1111/ans.12669.

75.Borzunov D.Y., Chevardin A.V. Ilizarov non-free bone plasty for extensive tibial defects. Int. Orthop., 2013, vol. 37, no. 4, pp. 709714. DOI: 10.1007/s00264-013-1799-3.

76.Brinker M.R., O'Connor D.P. Outcomes of tibial nonunion in older adults following treatment using the Ilizarov method. J. Orthop. Trauma, 2007, vol. 21, no. 9, pp. 634-642. DOI: 10.1097/BOT.0b013e318156c2a2.

77.Bruno A.A., Kirienko A., Peccati A., Dupplicato P., De Donato M., Arnaldi E., Portinaro N. Knee arthrodesis by the Ilizarov method in the treatment of total knee arthroplasty failure. Knee, 2017, vol. 24, no. 1, pp. 91-99. DOI: 10.1016/j.knee.2016.11.002.

78.Calif E., Stein H., Lerner A. The Ilizarov external fixation frame in compression arthrodesis of large, weight bearing joints. Acta Orthop. Belg., 2004, vol. 70, no. 1, pp. 51-56.

79.Carmichael K.D., Maxwell S.C., Calhoun J.H. Recurrence rates of burn contracture ankle equinus and other foot deformities in children treated with Ilizarov fixation. J. Pediatr. Orthop., 2005, vol. 25, no. 4, pp. 523-528.

80.Cattaneo R., Villa A., Catagni M.A., Bell D. Lengthening of the humerus using the Ilizarov technique. Description of the method and report of 43 cases. Clin. Orthop. Relat. Res., 1990, no. 250, pp. 117-124.

81.Chaddha M., Gulati D., Singh A.P., Singh A.P., Maini L. Management of massive posttraumatic bone defects in the lower limb with the Ilizarov technique. Acta Orthop. Belg., 2010, vol. 76, no. 6, pp. 811-820.

82. Cierny G. 3rd, Zorn K.E. Segmental tibial defects. Comparing conventional and Ilizarov methodologies. Clin. Orthop. Relat. Res., 1994, no. 301, pp. 118-123.

83.Dammerer D., Kirschbichler K., Donnan L., Kaufmann G., Krismer M., Biedermann R. Clinical value of the Taylor Spatial Frame: a comparison with the Ilizarov and Orthofix fixators. J. Child. Orthop., 2011, vol. 5, no. 5, pp. 343-349. DOI: 10.1007/s11832-0110361-3.

84.Dujardyn J., Lammens J. Treatment of delayed union or non-union of the tibial shaft with partial fibulectomy and an Ilizarov frame. Acta Orthop. Belg., 2007, vol. 73, no. 5, pp. 630-634.

85. El-Alfy B.S. Unhappy triad in limb reconstruction: Management by Ilizarov method. World J. Orthop., 2017, vol. 8, no. 1, pp. $42-48$. DOI: 10.5312/wjo.v8.i1.42.

86.Eylon S., Porat S., Bor N., Leibner E.D. Outcome of Ilizarov ankle arthrodesis. Foot Ankle Int., 2007, vol. 28, no. 8, pp. 873-879. DOI: 10.3113/FAI.2007.0873.

87.Fabry K., Lammens J., Delhey P., Stuyck J., Pellenberg U.Z. Ilizarov's method: a solution for infected bone loss. Eur. J. Orthop. Surg. Traumatol., 2006, vol. 16, no. 2, pp. 103-109. DOI: 10.1007/s00590-005-0052-1.

88.Farmanullah, Khan M.S., Awais S.M. Evaluation of management of tibial non-union defect with Ilizarov fixator. J. Ayub. Med. Coll. Abbottabad., 2007, vol. 19, no. 3, pp. 34-36.

89.Fragomen A.T., Borst E., Schachter L., Lyman S., Rozbruch S.R. Complex ankle arthrodesis using the Ilizarov method yields high rate of fusion. Clin. Orthop. Relat. Res., 2012, vol. 470, no. 10, pp. 2864-2873. DOI: 10.1007/s11999-012-2470-9.

90.Freedman J.A., Watts H., Otsuka N.Y. The Ilizarov method for the treatment of resistant clubfoot: is it an effective solution? 
J. Pediatr. Orthop., 2006, vol. 26, no. 4, pp. 432-437. DOI: 10.1097/01.bpo.0000226276.70706.0e.

91.Hall J.A., Beuerlein M.J., McKee M.D.; Canadian Orthopaedic Trauma Society. Open reduction and internal fixation compared with circular fixator application for bicondylar tibial plateau fractures. J. Bone Joint Surg. Am., 2009, vol. 91, no. Suppl. 2, pt. 1, pp. 74-88. DOI: 10.2106/JBJS.G.01165.

92.Hosny G., Fadel M. Ilizarov external fixator for open fractures of the tibial shaft. Int. Orthop., 2003, vol. 27, no. 5, pp. 303-306. DOI: 10.1007/s00264-003-0476-3.

93.Hosny G.A. Humeral lengthening and deformity correction. J. Child. Orthop., 2016, vol. 10, no. 6, pp. 585-592. DOI: 10.1007/ s11832-016-0789-6.

94.Inan M., Halici M., Ayan I., Tuncel M., Karaoglu S. Treatment of type IIIA open fractures of tibial shaft with Ilizarov external fixator versus unreamed tibial nailing. Arch. Orthop. Trauma Surg., 2007, vol. 127, no. 8, pp. 617-623. DOI: 10.1007/s00402-007-0332-9.

95.Khan M.S., Rashid H., Umer M., Qadir I., Hafeez K., Iqbal A. Salvage of infected non-union of the tibia with an Ilizarov ring fixator. J. Orthop. Surg. (Hong Kong), 2015, vol. 23, no. 1, pp. 52-55. DOI: 10.1177/230949901502300112.

96.Khan M.S., Raza W., Ullah H., Khan A.S., Siraj M., Askar Z. Outcome of ilizarov fixator in complex non-union of long bones. J. Pak. Med. Assoc., 2015, vol. 65, no. 11 Suppl. 3, pp. S147-S151.

97.Khanfour A.A. Versatility of Ilizarov technique in difficult cases of ankle arthrodesis and review of literature. Foot Ankle Surg., 2013, vol. 19, no. 1, pp. 42-47. DOI: 10.1016/j.fas.2012.10.001.

98.Krishnan A., Pamecha C., Patwa J.J. Modified Ilizarov technique for infected nonunion of the femur: the principle of distractioncompression osteogenesis. J. Orthop. Surg. (Hong Kong), 2006, vol. 14, no. 3, pp. 265-272. DOI: 10.1177/230949900601400307.

99.Kristiansen L.P., Steen H., Reikerås O. No difference in tibial lengthening index by use of Taylor spatial frame or Ilizarov external fixator. Acta Orthop., 2006, vol. 77, no. 5, pp. 772-777. DOI: 10.1080/17453670610012971.

100. Kucukkaya M., Kabukcuoglu Y., Tezer M., Kuzgun U. Management of childhood chronic tibial osteomyelitis with the Ilizarov method. J. Pediatr. Orthop., 2002, vol. 22, no. 5, pp. 632-637.

101. McGarvey W.C., Burris M.W., Clanton T.O., Melissinos E.G. Calcaneal fractures: indirect reduction and external fixation. Foot Ankle Int., 2006, vol. 27, no. 7, pp. 494-499. DOI: 10.1177/107110070602700703.

102. McNally M., Ferguson J., Kugan R., Stubbs D. Ilizarov Treatment Protocols in the Management of Infected Nonunion of the Tibia. J. Orthop. Trauma, 2017, vol. 31, no. Suppl. 5, pp. S47-S54. DOI: 10.1097/BOT.0000000000000987.

103. Meleppuram J.J., Ibrahim S. Experience in fixation of infected non-union tibia by Ilizarov technique - a retrospective study of 42 cases. Rev. Bras. Ortop., 2016, vol. 52, no. 6, pp. 670-675. DOI: 10.1016/j.rboe.2016.11.008.

104. Menakaya C.U., Rigby A.S., Hadland Y., Barron E., Sharma H. Fracture healing following high energy tibial trauma: Ilizarov versus Taylor Spatial Frame. Ann. R. Coll. Surg. Engl., 2014, vol. 96, no. 2, pp. 106-110. DOI: 10.1308/003588414X138245116 50335.

105. Morasiewicz L., Orzechowski W., Kulej M., Stepniewski M. The results of treatment of bone defects and K.I. non-union within the femoral shaft with shortening of femur using Ilizarov method. Ortop. Traumatol. Rehabil., 2007, vol. 9, no. 4, pp. 366-376.

106. Novikov, K.N. Subramanyam, S.O. Muradisinov, O.S. Novikova, E.S. Kolesnikova. Cosmetic lower limb lengthening by Ilizarov apparatus: what are the risks? Clin. Orthop. Relat. Res., 2014, vol. 472, no 11, pp. 3549-3556. DOI: 10.1007/s11999-014-3782-8.

107. O'Neill B.J., Fox C.M., Molloy A.P., O'hEireamhoin S., Moore D.P. The use of circular external fixators in the management of lower limb trauma in Dublin: a single surgeon's 20-year experience. Ir. J. Med. Sci., 2016, vol. 185, no 1, pp. 133-138. DOI: 10.1007/ s11845-014-1240-y.

108. Oostenbroek H.J., van Roermund P.M. Arthrodesis of the knee after an infected arthroplasty using the Ilizarov method. J. Bone Joint Surg. Br., 2001, vol. 83, no 1, pp. 50-54.

109. Paley D., Catagni M.A., Argnani F., Villa A., Benedetti G.B., Cattaneo R. Ilizarov treatment of tibial nonunions with bone loss. Clin. Orthop. Relat. Res., 1989, no 241, pp. 146-165.

110. Paley D., Maar D.C. Ilizarov bone transport treatment for tibial defects. J. Orthop. Trauma, 2000, Vol. 14, no 2. pp. 76-85.

111. Pathania V.P., Sharma A.K., Joshi G.R., John J.T. Correction of Lower Limb Deformities Using Ilizarov's Technique. Med. J. Armed Forces India, 2005, vol. 61, no 4, pp. 322-325. DOI: 10.1016/S0377-1237(05)80054-1.

112. Patil S., Montgomery R. Management of complex tibial and femoral nonunion using the Ilizarov technique, and its cost implications. J. Bone Joint Surg. Br., 2006, vol. 88, no 7, pp. 928-932. DOI: 10.1302/0301-620X.88B7.17639.

113. Ramos T., Karlsson J., Eriksson B.I., Nistor L. Treatment of distal tibial fractures with the Ilizarov external fixator - a prospective observational study in 39 consecutive patients. BMC Musculoskelet. Disord., 2013, vol. 14, pp. 30. DOI: 10.1186/1471-2474-14-30.

114. Evaluation of tibial condyle fractures treated with Ilizarov fixation, a prospective study / R.S. Reddy, C.Y. Kumar, H.M. Shah, D.K. Golla, D.J.N. Ganesh, P.A. Kumar. J. Clin. Diagn. Res., 2014, vol. 8, no 11, pp. LC05-LC07. DOI: 10.7860/ JCDR/2014/9564.5117.

115. Rohilla R., Wadhwani J., Devgan A., Singh R., Khanna M. Prospective randomised comparison of ring versus rail fixator in infected gap nonunion of tibia treated with distraction osteogenesis. Bone Joint J., 2016, vol. 98-B, no 10, pp. 1399-1405. DOI: 10.1302/0301-620X.98B10.37946.

116. Sakurakichi K., Tsuchiya H., Kabata T., Yamashiro T., Watanabe K., Tomita K. Correction of juxtaarticular deformities in children using the Ilizarov apparatus. J. Orthop. Sci., 2005, vol. 10, no. 4, pp. 360-366.

117. Salem K.H., Kinzl L., Schmelz A. Ankle arthrodesis using Ilizarov ring fixators: a review of 22 cases. Foot Ankle Int., 2006, vol. 27, no. 10, pp. 764-770.

118. Song H.R., Cho S.H., Koo K.H., Jeong S.T., Park Y.J., Ko J.H. Tibial bone defects treated by internal bone transport using the Ilizarov method. Int. Orthop., 1998, vol. 22, no. 5, pp. 293-297.

119. Tafazal S., Madan S.S., Ali F., Padman M., Swift S., Jones S., Fernandes J.A. Management of paediatric tibial fractures using two types of circular external fixator: Taylor spatial frame and Ilizarov circular fixator. J. Child. Orthop., 2014, vol. 8, no. 3, pp. $273-279$. DOI: $10.1007 / \mathrm{s} 11832-014-0583-2$.

120. Tomić S., Bumbasirević M., Lesić A., Mitković M., Atkinson H.D. Ilizarov frame fixation without bone graft for atrophic humeral shaft nonunion: 28 patients with a minimum 2-year follow-up. J. Orthop. Trauma, 2007, vol. 21, no. 8, pp. 549-556. 
121. Tong K., Zhong Z., Peng Y., Lin C., Cao S., Yang Y., Wang G. Masquelet technique versus Ilizarov bone transport for reconstruction of lower extremity bone defects following posttraumatic osteomyelitis. Injury, 2017, vol. 48, no. 7, pp. 1616-1622. DOI: 10.1016/j. injury.2017.03.042.

122. Vanderstappen J., Lammens J., Berger P., Laumen A. Ilizarov bone transport as a treatment of congenital pseudarthrosis of the tibia: a long-term follow-up study. J. Child. Orthop., 2015, vol. 9, no. 4, pp. 319-324. DOI: 10.1007/s11832-015-0675-7.

123. Vidyadhara S., Rao S.K. Ilizarov treatment of complex tibial pilon fractures. Int. Orthop., 2006, vol. 30, no. 2, pp. $113-117$.

124. Villa A., Paley D., Catagni M.A., Bell D., Cattaneo R. Lengthening of the forearm by the Ilizarov technique. Clin. Orthop. Relat. Res., 1990, no. 250, pp. 125-137.

125. Wang H., Wei X., Liu P., Fu Y.H., Wang P.F., Cong Y.X., Zhang B.F., Li Z., Lei J.L., Zhang K., Zhuang Y. Quality of life and complications at the different stages of bone transport for treatment infected nonunion of the tibia. Medicine (Baltimore), 2017, vol. 96, no. 45, pp. e8569. DOI: 10.1097/MD.0000000000008569.

126. Wani N.B., Syed B. Ilizarov ring fixator in the management of infected non-unions of tibia. SICOT J., 2015, vol. 1, pp. 22. DOI: $10.1051 /$ sicotj/2015022.

127. Williams M.O. Long-term cost comparison of major limb salvage using the Ilizarov method versus amputation. Clin. Orthop. Relat. Res., 1994, no. 301, pp. 156-158.

128. Wu Y., Yin Q., Rui Y., Sun Z., Gu S. Ilizarov technique: Bone transport versus bone shortening-lengthening for tibial bone and soft-tissue defects. J. Orthop. Sci., 2017, vol. 23, no. 2, pp. 341-345. DOI: 10.1016/j.jos.2017.12.002.

129. Xu K., Fu X., Li Y.M., Wang C.G., Li Z.J. A treatment for large defects of the tibia caused by infected nonunion: Ilizarov method with bone segment extension. Ir. J. Med. Sci., 2014, vol. 183, no. 3, pp. 423-428. DOI: 10.1007/s11845-013-1032-9

130. Yin P., Ji Q., Li T., Li J., Li Z., Liu J., Wang G., Wang S., Zhang L., Mao Z., Tang P. A Systematic Review and Meta-Analysis of Ilizarov Methods in the Treatment of Infected Nonunion of Tibia and Femur. PLoS One, 2015, vol. 10, no. 11, pp. e0141973. DOI: 10.1371/journal.pone.0141973.

131. Shevtsov V.I., Makushin V.D., Kuftyrev L.M., Soldatov Iu.P. Profilaktika i ustranenie vozmozhnykh oslozhnenii lechebnogo protsessa pri osteosinteze psevdoartrozov i defektov kostei verkhnei konechnosti [Prevention and elimination of possible complications in treatment by osteosynthesis of pseudoarthroses and defects of the upper limb bones]. Genij Ortopedii, 2003 , no. 2, pp. 103-107. (in Russian)

132. Sella E.J. Prevention and management of complications of the Ilizarov treatment method. Foot Ankle Spec., 2008, vol. 1, no. 2, pp. 105-107. DOI: 10.1177/1938640008315349.

133. Dahl M.T., Gulli B., Berg T. Complications of limb lengthening. A learning curve. Clin. Orthop. Relat. Res., 1994, no. 301, pp. 1018.

134. Slomka R. Complications of ring fixators in the foot and ankle. Clin. Orthop. Relat. Res., 2001, no. 391, pp. 115-122.

Received: 15.10 .2018

\section{Information about the authors:}

1. Yuri P. Soldatov, M.D., Ph.D., Professor, Russian Ilizarov Scientific Center for Restorative Traumatology and Orthopaedics, Kurgan, Russian Federation

2.Maksim V. Stogov, Ph.D. of Biological Sciences,

Russian Ilizarov Scientific Center for Restorative Traumatology and Orthopaedics, Kurgan, Russian Federation, Email: stogo_off@list.ru

3. Evgeny N. Ovchinnikov, Ph.D. of Biological Sciences,

Russian Ilizarov Scientific Center for Restorative Traumatology and Orthopaedics, Kurgan, Russian Federation

4. Alexander V. Gubin, M.D., Ph.D.,

Russian Ilizarov Scientific Center for Restorative Traumatology and Orthopaedics, Kurgan, Russian Federation,

Email: shugu19@gubin.spb.ru

5. Natalia V. Gorodnova, Ph.D. of Economic Sciences, professor,

Ural Federal University, Ekaterinburg, Russian Federation,

Email: n.v.gorodnova@urfu.ru 